\title{
TITLE:
}

\section{Size and Viscoelasticity of Spatially Confined Multilamellar Vesicles}

\section{$\operatorname{AUTHOR}(S):$}

Fujii, Shuji; Isono, Yoshinobu; Richtering, Walter

\section{CITATION:}

Fujii, Shuji ...[et al]. Size and Viscoelasticity of Spatially Confined Multilamellar Vesicles. 物 性研究 2006, 87(1): 139-140

ISSUE DATE:

2006-10-20

URL:

http://hdl.handle.net/2433/110609

RIGHT: 


\title{
Size and Viscoelasticity of
}

\section{Spatially Confined Multilamellar Vesicles ${ }^{1}$}

\author{
Dept. of Chem., Nagaoka Univ. of Technol. Shuji Fujiï ${ }^{2}$ Yoshinobu Isono \\ IPC RWTH Aachen Univ. Walter Richtering ${ }^{3}$
}

マルチラメラベシクル相(MLV)の粘弾性特性をズリ速度とサンプル厚の関数として調べた。粘 弾性特性は、(1)高ズリ速度領域での Shear-thinning viscosity、(2)低ズリ速度領域での Shear-thickening viscosity の 2 つに分類された。前者において MLV 半径はサンプル厚に依存せ ず、実行表面張力 $\sigma_{\text {eff }}$ と粘性応力との力学的バランスで決まることが明らかとなった。後者におい て MLV 半径はサンプル厚の減少に伴い増加し、MLV 半径が然f のみでは決定されない。これは、 空間拘束効果によるベシクル構造安定性の変化が粘弾性挙動に強く影響することを示す。

\section{Introduction}

Multilamellar vesicle (MLV) phase is obtained by shearing the lamellar phase. Detailed investigations by combining scattering experiments with rheometry yielded an "orientation diagram" on the development of the MLV structure [1]. Interestingly the orientation diagram suggested that the MLV radius is a decreasing function of the shear rate, while this process consists of a shear-thickening and shear-thinning regime. In addition, the orientation diagram is effectively modified by the sample thickness. Thus, the sample thickness seems to be a significant parameter for the dynamics of MLVs. In this study, we focus on the viscoelasticity of MLVs with the development of MLV radius as a function of the sample thickness as well as the shear force.

\section{Size effect on $M L V s$ radius}

Non-ionic surfactant, tri-ethylene glycol mono-decylether $\left(\mathrm{C}_{10} \mathrm{E}_{3}\right)$ purchased from Nikko chemicals Co.,Ltd., was dissolved into deutrium oxide, $\mathrm{D}_{2} \mathrm{O}$, with a weight fraction of $40 \%$. MLV was prepared by following previous report [2]. Microscopy under shear was performed by using a plate-plate shear cell. MLV radius was estimated from the intensity profile of the 2D-FFT images. Viscoelastic functions were measured using Bohlin CVO-120 rheometer with

1 Eur. Phys. J. E 19 (2006) 139-148

2 E-mail:sfujii@chem..nagaokaut.ac.jp

3 E-mail:richtering@rwth-aachen.de 
a plate-plate shear cell.

Figure 1 shows the gap size dependence of $R_{M L V}$. At the large gap sizes, $R_{M L V}$ is independent of $D$, while the MLVs start to grow when $D$ is reduced smaller than a threshold gap size, $D c$. In figure 1, our results were by re-plotted as a function of the inverse of shear stress. MLV radius, $R_{M L V}$, is expressed as follows.

$$
R_{M L V} \propto \sigma_{\text {eff }} / \eta \gamma
$$

Where $\sigma_{\text {eff }}$ is an effective surface tension and defined by bending modulus $K$ and compression modulus $B$ of bilayer membranes, $\sigma_{\text {eff }}=(K B)^{1 / 2}$ [3]. The evolution of $R_{M L V}$ with $1 / \eta \gamma$ at high shear rates and large gap sizes $(>D c)$ shows a master curve which passes through the origin, while the data corresponding to the small gap sizes $(<D c)$ get off the master curve. The slope, $\sigma_{\text {eff }}=(K B)^{1 / 2}$, was $2.1 \pm 0.15 \times 10^{-4}\left(\mathrm{Nm}^{-1}\right)$. The same parameter, $(K B)^{1 / 2}$, can be extracted from a Caille parameter estimated from the structural factor of SAXS and SANS data. Our estimated value is quite similar to that obtained for the other surfactant systems. This result shows that the MLV structure at small gap size is affected by a confinement effect.
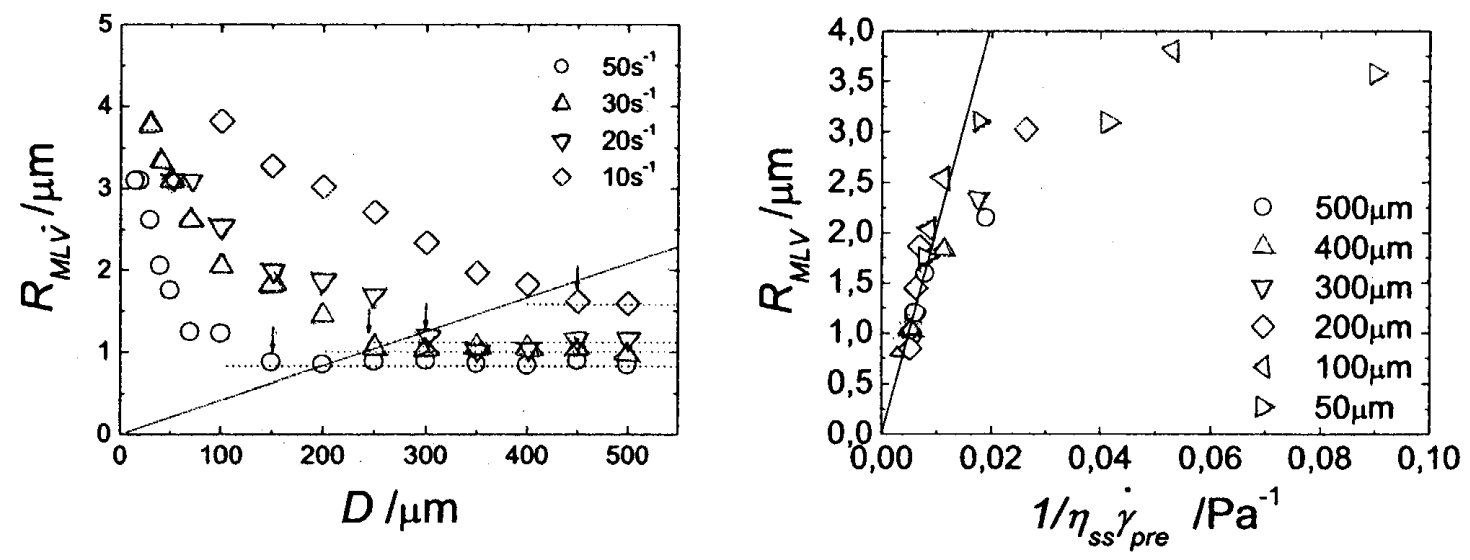

Figure 1: $R_{M L V}$ as a function of gap size, $D$, (1.h.s.) and $R_{M L V}$ as a function of the inverse of the shear stress, $1 / \eta \gamma$ (r.h.s.).

\section{References}

[1] O. Diat, D. Roux and F. Nallet, J. Phys. II (France) 3 (1993), 1427.

[2] F. Nettesheim, J. Zipfel, U. Olsson, F. Renth, P. Lindner and W. Richtering, Langmuir 19 (2003), 3603.

[3] P.-G. de Gennes, J. Prost, The Physics of Liquid Crystals (Clarendon Press, Oxford, 1993). 